Check for updates

London

Cite this as: BMJ 2021;372:n516 http://dx.doi.org/10.1136/bmj.n516 Published: 22 February 2021

\title{
Covid-19: Plans to share vaccines aren’t enough, says charity
}

\section{Matthew Limb}

New pledges by leaders of the $\mathrm{G}_{7}$ group of richest countries to intensify cooperation on covid-19 and commit \$7.5bn ( $€ 5.3 \mathrm{bn}$; €6.2bn) to sharing supplies of vaccine around the world are insufficient, a leading charity has said.

Oxfam said that steps to increase the supply of vaccines to poorer countries, though welcome, would not be enough to deal with the covid-19 threat and to redress "immoral" inequalities of access.

Meanwhile, the UK is being urged to act more quickly on its commitment to make "surplus" vaccines available to developing countries and to explain when it would have spare doses.

The leaders of the $\mathrm{G}_{7}$ countries (UK, US, Canada, Japan, Germany, France, and Italy, plus the European Union) pledged new funding on 19 February for the Covax scheme, which aims to get at least 1.3 billion doses of vaccine to 92 low and middle income countries by the end of 2021. The scheme is co-led by the vaccine alliance body Gavi, the World Health Organization, and the Coalition for Epidemic Preparedness Innovations.

The G7 leaders held a virtual summit, chaired by UK prime minister Boris Johnson, with US president Joe Biden participating for the first time. They said in a statement, "We reaffirm our support for all pillars of the Access to COVID-19 Tools Accelerator (ACT-A), its COVAX facility, and affordable and equitable access to vaccines, therapeutics and diagnostics, reflecting the role of extensive immunisation as a global public good."1

Biden pledged up to \$4bn in US support. The EU announced it was doubling its contribution from $€_{500 m}$ to $€ 1 \mathrm{bn},{ }^{2}$ Germany pledged a further $€ 900 m$, while the UK is allocating $£ 548 \mathrm{~m}$ to Covax.

But there remains criticism that worldwide distribution of vaccines is uneven and unfair. Ten countries have administered $75 \%$ of all vaccinations worldwide, while 130 countries had yet to receive a single dose, said the UN.

Max Lawson, Oxfam's head of inequality policy, said, "Between them, G7 nations have secured enough vaccines for every one of their citizens to be vaccinated three times over, while many poor countries are yet to receive a single dose.” He said the latest pledge represented only limited progress and large parts of Africa and Asia would still be left waiting for unwanted leftover vaccines to "trickle down to them," which was "immoral" and posed a risk to global health.

“The longer huge swathes of the world's protection are denied protection, the greater the threat that virus mutations will threaten us all," Lawson said.
Johnson told the summit that the UK, which has ordered around 450 million vaccine doses, would donate most of the UK's "surplus" vaccine supply to poorer countries. This was dependent on reliable supply chains and whether new vaccines were needed for variant strains or as a booster in the autumn, the UK government said.

The BMA welcomed the gesture of "solidarity" but called for more detail. "The government must now be forthcoming and transparent over what the UK's commitment will be and how this will be achieved," said its deputy chair of council, David Wrigley.

Johnson said he wanted to "ensure that we distribute vaccines at cost around the world-to make sure everybody gets the vaccines that they need so that the whole world can come through this pandemic together."

Ngozi Okonjo-Iweala, the new head of the World Trade Organization, told the BBC that the UK should donate vaccines to developing countries now rather than waiting until it has a surplus.

In their joint statement the $\mathrm{G}_{7}$ leaders said the covid-19 pandemic showed that the world needed stronger defences against future risks to global health security and pledged to "make 2021 a turning point for multilateralism" in shaping a recovery that would "build back better for all."

1 Joint statement of G7 leaders. 19 Feb 2021. https://www.g7uk.org/jointstatement-of-g7-leaders-19-february-2021.

European Commission. EU doubles contribution to COVAX to €1 billion to ensure safe and effective vaccines for low and middle-income countries. 19 Feb 2021. https://ec.europa.eu/international-partnerships/news/eudoubles-contribution-covax-eu1-billion-ensure-safe-and-effective-vaccineslow-and-middle_en.

This article is made freely available for use in accordance with BMJ's website terms and conditions for the duration of the covid-19 pandemic or until otherwise determined by BMJ. You may use, download and print the article for any lawful, non-commercial purpose (including text and data mining) provided that all copyright notices and trade marks are retained. 